\title{
Altered concentrations of gonadotrophin, prolactin and GnRH receptors, and endogenous steroids in the abdominal testes of adult unilaterally cryptorchid rats
}

\author{
A. Bergh*, H. Nikula $\uparrow$, J.-E. Damber $\ddagger$, R. Clayton $\S$ and I. Huhtaniemi $\dagger$ \\ Departments of ${ }^{*}$ Anatomy, ${ }^{*}$ Pathology and $\ddagger$ Clinical Chemistry, University of Umea, Sweden, and \\ $\dagger$ Departments of Clinical Chemistry, and Immunology and Bacteriology, University of Helsinki, \\ Finland, and §Department of Medicine, University of Birmingham, Birmingham B15 2TH, U.K.
}

\begin{abstract}
Summary. Testicular descent was prevented unilaterally in newborn rats by cutting the gubernaculum testis. At 100 days of age, the number of Leydig and Sertoli cells per testis, the concentration of receptors for $\mathrm{LH}, \mathrm{FSH}$, prolactin and GnRH, and endogenous concentrations of progesterone and testosterone were determined. The weight of the abdominal testes was reduced by $80 \%$, but in spite of this they contained as many Sertoli $\left(32.8 \pm 1.3 \times 10^{6}\right.$, mean \pm s.e.m., $\left.n=6\right)$ and Leydig $(28.2 \pm 1.7 \times$ $\left.10^{6}\right)$ cells as did scrotal testes $\left(32.1 \pm 2.5 \times 10^{6}\right.$ and $24.3 \pm 1.2 \times 10^{6}$ respectively). The numbers of receptors for $\mathrm{LH}(3 \cdot 2 \pm 0.2$ and $1 \cdot 0 \pm 0.2 \mathrm{pmol} /$ testis, mean \pm s.e.m., $n=$ $11)$, FSH (358 \pm 11.0 and $96.3 \pm 12.6 \mathrm{fmol} /$ testis $)$ and prolactin $(535 \pm 32.7$ and $92.4 \pm$ $13.2 \mathrm{fmol} /$ testis $)$ were reduced $(P<0.001)$ in abdominal testes, but the number of GnRH receptors was unaffected $(8.9 \pm 1.4$ and $12.1 \pm 1.8 \mathrm{fmol} /$ testis, $n=6)$. Testicular testosterone concentration $(30.9 \pm 4.4$ vs $15.4 \pm 3.2 \mathrm{ng} / \mathrm{g}, n=11, P<$ $0.001)$, but not that of progesterone $(0.87 \pm 0.10 \mathrm{vs} 1.01 \pm 0.21 \mathrm{ng} / \mathrm{g})$, was decreased in abdominal testes. The decreased receptor and androgen values reflect functional disturbances in the abdominal testes. The changed local milieu within abdominal testes may reduce hormone receptor concentrations which are then involved in the observed Leydig cell dysfunction.
\end{abstract}

\section{Introduction}

Experimental cryptorchidism induced in adult rats results in profound changes in all main cell types of the testis. Almost all post-meiotic germinal cells are damaged and later lost (VanDemark \& Free, 1970). Sertoli cells are structurally altered (Kerr, Rich \& de Kretser, 1979a) and the production of androgen-binding protein, ABP (Hagenäs, Ritzén, Svensson \& Hansson, 1978), is depressed. Leydig cell morphology is changed and testosterone secretion in vivo is low (Kerr et al., 1979b). The mechanisms of these changes are unknown, and may be different for different models of cryptorchidism. For instance, when unilateral cryptorchidism is induced in adult rats it results in Leydig cell hypertrophy (Risbridger, Kerr, Peake \& de Kretser, 1981) but when induced in newborn rats the Leydig cell size is subnormal (Bergh \& Damber, 1978).

Experimental cryptorchidism induced in adult rats decreases the number of FSH, $\mathrm{LH}$ and prolactin receptors (Hagenäs et al., 1978; Hochberg, Amit, Youdim \& Jehuda, 1983). The reason behind these changes is unknown but, since they also occur in unilateral abdominal testes, local factors within the testis may be involved. However, it is not known whether this or other forms of cryptorchidism influences the number of Sertoli and Leydig cells. Consequently, differences in receptor numbers are difficult to interpret. Therefore, the effect of experimental unilateral

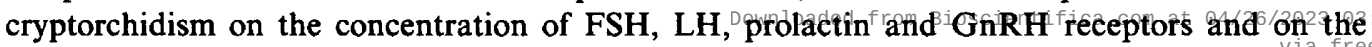


number of Sertoli and Leydig cells was investigated to characterize the testicular malfunction when descent was prevented at birth.

\section{Materials and Methods}

Unilateral cryptorchidism was induced in newborn Sprague-Dawley rats by cutting the gubernaculum testis (Bergh \& Helander, 1978). At 100 days of age the testes were examined morphologically and testicular hormone receptors and steroids were measured.

\section{Morphology}

The testes of 6 unilaterally cryptorchid rats were fixed by vascular perfusion as previously described. The fixative contained $4 \%$ formaldehyde, $3 \%$ glutaraldehyde and $0.05 \%$ picric acid in $0.05 \mathrm{M}$-cacodylate buffer (Bergh \& Helander, 1978). Testicular morphology was studied at $\times 1000$ magnification on $1 \mu \mathrm{m}$ thick plastic sections stained with toluidine blue. Leydig and Sertoli cell numbers per testis were determined stereologically using the formula $N_{V}=\left(K \times N_{A}^{3 / 2}\right) /(\beta \times$ $\mathrm{V}_{\mathrm{V}}{ }^{1 / 2}$ ) (see Weibel, 1979). According to this formula cellular number per unit volume of tissue $\left(\mathrm{N}_{\mathrm{V}}\right)$ can be determined by direct measurements of the number of cell nuclei (assuming cells to be mononuclear) per test area $\left(\mathrm{N}_{\mathrm{A}}\right)$ and the volume density of nuclei $\left(\mathrm{V}_{\mathrm{V}}\right) \mathrm{K}$ is a factor describing the size distribution of nuclei and $K=1$ except when the nuclear size varies greatly (see Weibel, 1979). This is not the case for Leydig and Sertoli cell nuclei. $\beta$ is a factor describing the shape of the nuclei, and $\beta=1.38$ for spheres. In the present calculations Sertoli and Leydig cell nuclei were assumed to be spherical although they are really elliptical. However, the error introduced, a slight overestimation of cell numbers, is $<10 \%$. Direct measurements of the long and short axes of the nuclei and a calculation of their $\beta$ value (see Weibel, 1979) showed that $\beta$ was 1.44 and 1.45 for abdominal and scrotal Leydig cells and 1.52 and 1.45 for abdominal and scrotal Sertoli cells. The number of cells per testis was calculated by multiplying testis weight with $\mathrm{N}_{\mathrm{V}}$ assuming testicular density to be close to 1 (Bergh \& Helander, 1978). Fixation and embedding, however, change the volume of the testis. The degree of shrinkage was determined by examining the diameter of free dissected unfixed seminiferous tubules from 4 other rats with the diameter obtained by measurements of the sections: the means \pm s.d. value declined from $366 \pm 10$ to $334 \pm 24 \mu \mathrm{m}$ for the scrotal testis, and from $181 \pm 26$ to $161 \pm 7 \mu \mathrm{m}$ for the abdominal testis. Consequently, testicular volume was decreased by 0.75 in the scrotal and 0.70 in the abdominal testes. The value for the number of cells per testis was corrected for this shrinkage. The microscope was equipped with a square lattice in the eyepiece for direct measurements of $N_{A}$ and $V_{V}$ of cell nuclei. A testicular area containing about 200 Sertoli and Leydig cell nuclei was measured per testis. In semithin, toluidine blue-stained, plastic sections from perfusion-fixed testes Leydig and Sertoli cells are easily recognized. The Leydig cells have a dark cytoplasm with numerous mitochondria and a nucleus with distinct nucleoli and peripheral clumps of heterochromatin. Leydig cells can generally be distinguished from macrophages and fibroblast-like cells. The macrophages have a lighter cytoplasm with large vacuoles, and the karyoplasm is lighter and has a more granulated appearance than in Leydig cells. The fibroblast-like cells have a more elongated nucleus. The Sertoli cell nuclei are recognized by the characteristic nucleoli and the lack of peripheral clumps of heterochromatin.

\section{Hormone preparations}

Highly purified hCG (CR-121; 13500 i.u./mg by bioassay) was prepared by Dr R. Canfield (Columbia University, New York, U.S.A.) and supplied by The Center for Population Research, NICHD. Partly purified hCG (Pregnyl; 3000 i.u./mg) was purchased from Organon (Oss, The Netherlands). Purified human FSH (NIADDK-hFSH-2, 3925 i.u./mg by bioassay) and human 
growth hormone (hGH, NIADDK-1-1) were donated by the National Pituitary Agency and NIADDK (Bethesda, MD, U.S.A.). Partly purified hFSH (Humegon) was a gift of Organon, and partly purified ovine prolactin was purchased from Sigma Chemical Co. (St Louis, MO, U.S.A.). The analogue used as a gonadotrophin releasing-hormone agonist was buserelin (D-Ser-(tBu) $\left.{ }^{6}\right)$-desGly ${ }^{10}$-GnRH $N$-ethylamide (GnRH-A) and was a gift of Hoechst AG (Frankfurt am Main, West Germany).

\section{Intratesticular testosterone and progesterone concentrations}

The concentrations of these steroids in the testis were measured by RIA from diethyl ether extracts of the $25000 \mathrm{~g}$ supernatants of the testicular homogenates (see below) (Jänne, Apter \& Vihko, 1974; Hammond, Viinikka \& Vihko, 1977). The recoveries of radioactive testosterone and progesterone in the supernatants, when added to the crude testicular homogenates and equilibrated $\left(2 \mathrm{~h}, 24^{\circ} \mathrm{C}\right)$, ranged from 71 to $76^{\circ} \%$ in the scrotal and abdominal testes. The final results were not corrected for the recoveries. The sensitivity of the testosterone and progesterone assays was $5 \mathrm{pg} /$ assay tube, and the coefficients of intra- and inter-assay variance were $4-6 \%$ and $9-12 \%$ respectively.

\section{Preparation of radioiodinated $h C G, h F S H, h G H$ and $G n R H-A$}

Highly purified hCG, hFSH and hGH were radioiodinated by the lactoperoxidase-glucose oxidase method (Enzymobeads; Bio-Rad, Richmond, CA, U.S.A.) according to the instructions of the manufacturer. The hormones were purified, and their specific activities and proportion of radioactivity present in biologically active hormone were measured as described by Catt, Ketelslegers \& Dufau (1976), Ketelslegers \& Catt (1978) and Huhtaniemi, Stewart, Channabasavaiah, Fraser \& Clayton (1984). The corrected specific activities of the three hormones were 70-80 $\mathrm{Ci} / \mathrm{g}, 20-25 \mathrm{Ci} / \mathrm{g}$ and $50-70 \mathrm{Ci} / \mathrm{g}$, respectively. GnRH-A was radioiodinated to a specific activity of $1000-1500 \mathrm{Ci} / \mathrm{g}$ as previously described (Clayton, Shakespear \& Marshall, 1979).

\section{Measurement of testicular $L H, F S H$, and prolactin and GnRH receptors}

The testes taken for receptor and hormone measurements were immediately frozen in liquid nitrogen and stored at $-70^{\circ} \mathrm{C}$ until required (within 1 month). The decapsulated testes were homogenized in $10 \mathrm{ml} / \mathrm{g}$ tissue of Dulbecco's phosphate-buffered saline $(0.14 \mathrm{M}-\mathrm{NaCl}, 0.0027 \mathrm{M}$ $\mathrm{KCl}, 0.0081 \mathrm{M}-\mathrm{Na}_{2} \mathrm{HPO}_{4}, 0.0015 \mathrm{M}-\mathrm{KH}_{2} \mathrm{PO}_{4}, 0.0005 \mathrm{M}-\mathrm{HgCl}_{2}$ and $\left.0.0007 \mathrm{M}-\mathrm{CaCl}_{2}\right)+0.1 \%$ bovine serum albumin (PBS-BSA, pH 7.4), and the homogenates were used as such for LH, FSH, and prolactin receptor measurements: 100 or $200 \mu \mathrm{l}$ samples of the homogenate were equilibrated (overnight at $23^{\circ} \mathrm{C}$ ) with 100000 c.p.m. of ${ }^{125} \mathrm{I}$-labelled hCG and $4 \mathrm{ng}$ non-radioactive hCG/tube, 25000 c.p.m. of ${ }^{125} \mathrm{I}$-labelled hFSH, or 150000 c.p.m. of ${ }^{125}$ I-labelled hGH (total volume $250-350$ $\mu 1)$. Non-specific binding was measured in matched samples in the presence of 50 i.u. hCG, 2 i.u. hFSH or $5 \mu \mathrm{g}$ ovine prolactin, respectively. Bound and free hormone were separated after 15 -fold dilution of the samples by centrifugation. The hCG concentration used $(0.7 \mathrm{nM})$ resulted in nearmaximal saturation of $\mathrm{LH}$ receptors (Catt et al., 1976), and the binding measured can be considered to be equal to the number of $\mathrm{LH}$ receptors in the tissue. The concentrations of labelled hFSH $(0 \cdot 2$ nM) and hGH (0.4 nM) were below those needed for receptor saturation (Catt et al., 1976; Huhtaniemi, Warren \& Catt, 1983) but since the $K_{\mathrm{a}}$ values of hFSH and hGH binding did not differ for scrotal and cryptorchid testes (see Text-fig. 1), the binding was proportional to, though not identical with, the number of FSH and prolactin (lactogen) receptors in the tissues. The similarity of the $K_{\mathrm{a}}$ values for LH, FSH and prolactin receptor binding between the scrotal and abdominal testes was tested with Scatchard analysis of the binding data to pools of 3-5 scrotal and abdominal testes, respectively. Scatchard plots were constructed from binding data obtained by incubating a 
constant amount of tissue homogenates and the iodinated hormones in the presence of increasing concentrations of hCG $(0.2-100 \mathrm{ng} /$ tube $)$, hFSH (0.03-300 ng/tube) or hGH (0.1-100 ng/tube).

A partly purified membrane preparation was used for testicular $\mathrm{GnRH}$ receptor measurements (Huhtaniemi et al., 1984). The testicular homogenates in PBS (see above) were centrifuged at $1000 \mathrm{~g}$ for $10 \mathrm{~min}$, and the supernatants were further centrifuged for $20 \mathrm{~min}$ at $25000 \mathrm{~g}$. The resulting pellet was resuspended in assay buffer ( $10 \mathrm{nM}$-Tris- $\mathrm{HCl}, \mathrm{pH} 7 \cdot 4,1 \mathrm{nM}$-dithiothreitol and $0.1 \% \mathrm{BSA}$; $1 \mathrm{ml} / \mathrm{g}$ original tissue) and used for receptor measurements: $100 \mu \mathrm{l}$ samples of the membrane preparation were incubated for $90 \mathrm{~min}$ at $4^{\circ} \mathrm{C}$ with $100 \mu 1^{125} \mathrm{I}$-labelled $\mathrm{GnRH}-\mathrm{A}\left(3 \times 10^{-11} \mathrm{M}\right)$ with and without a 100-fold excess of unlabelled GnRH-A in a total volume of $300 \mu 1$. The reaction was stopped by 15-fold dilution of the sample with PBS, and the membranes were separated (under vacuum) by filtration through Whatman $\mathrm{GF} / \mathrm{C}$ glass fibre filters. The concentration of the radioactive ligand used was non-saturating (Clayton et al., 1979) but since no difference was found in the affinities of GnRH-A to the scrotal and abdominal testis (see Text-fig. 1), the binding measured was proportional to the number of GnRH receptors in the tissue samples. The Scatchard plots were constructed from binding measurements carried out in the presence of increasing concentrations of ${ }^{125}$ I-labelled GnRH-A (10 000-200 000 c.p.m./tube).

The average number of receptors per target cell was obtained by dividing the average total number of receptors per testis (the molar concentration multiplied by Avogadro's number) with the average number of target cells per testis, assuming FSH receptors to be present in Sertoli cells and the others in Leydig cells.

\section{Results}

The weight (mean \pm s.e.m.) of the abdominal testis was clearly reduced $(0.42 \pm 0.05 \mathrm{~g}, n=11)$ compared with that of the scrotal testis $(2.04 \pm 0.05 \mathrm{~g}, n=11)$ but the mean $( \pm$ s.e.m.) number of Sertoli cells $\left(32.8 \pm 1.3 \times 10^{6}\right.$ and $32.1 \pm 2.5 \times 10^{6}$ in scrotal and abdominal testes, respectively, $n$ $=6$ for both $)$ and Leydig cells $\left(28.2 \pm 1.7 \times 10^{6}\right.$ and $24.3 \pm 1.2 \times 10^{6}$ in scrotal and abdominal

Table 1. Hormone receptor concentrations (mean \pm s.e.m.) in adult unilaterally cryptorchid rats

\begin{tabular}{|c|c|c|c|c|}
\hline Receptors & $\begin{array}{l}\text { No. of } \\
\text { animals }\end{array}$ & Measurement & $\begin{array}{l}\text { Scrotal } \\
\text { testis }\end{array}$ & $\begin{array}{l}\text { Abdominal } \\
\text { testis }\end{array}$ \\
\hline FSH & 11 & $\begin{array}{l}\mathrm{fmol} / \mathrm{g} \\
\mathrm{fmol} / \text { testis } \\
\text { no./Sertoli cell }\end{array}$ & $\begin{array}{c}181 \pm 5 \cdot 27 \\
358 \pm 11 \cdot 0 \\
6571\end{array}$ & $\begin{array}{c}208 \pm 18 \cdot 6 \\
96 \cdot 3 \pm 12 \cdot 6^{*} \\
1806\end{array}$ \\
\hline LH & 11 & $\begin{array}{l}\mathrm{pmol} / \mathrm{g} \\
\mathrm{pmol} / \text { testis } \\
\text { no./Leydig cell }\end{array}$ & $\begin{array}{c}1.54 \pm 0.075 \\
3.15 \pm 0.20 \\
67245\end{array}$ & $\begin{array}{l}2 \cdot 48 \pm 0 \cdot 18^{*} \\
0 \cdot 99 \pm 0 \cdot 18^{*} \\
24526\end{array}$ \\
\hline Prolactin & 11 & $\begin{array}{l}\mathrm{fmol} / \mathrm{g} \\
\mathrm{fmol} / \text { testis } \\
\text { no./Leydig cell }\end{array}$ & $\begin{array}{c}263 \pm 15 \cdot 5 \\
535 \pm 32 \cdot 7 \\
11421\end{array}$ & $\begin{array}{c}193 \pm 14 \cdot 2^{*} \\
192 \cdot 4 \pm 13 \cdot 2^{*} \\
2289\end{array}$ \\
\hline GnRH & 6 & $\begin{array}{l}\mathrm{fmol} / \mathrm{g} \\
\mathrm{fmol} / \text { testis } \\
\text { no./Leydig cell }\end{array}$ & $\begin{array}{c}4.18 \pm 0.65 \\
8.09 \pm 1 \cdot 4 \\
189\end{array}$ & $\begin{array}{c}26.8 \pm 4 \cdot 12^{*} \\
12 \cdot 1 \pm 1 \cdot 8 \\
300\end{array}$ \\
\hline Oestradiol $\dagger$ & 6 & $\begin{array}{l}\mathrm{fmol} / \mathrm{g} \\
\mathrm{fmol} / \text { testis } \\
\text { no./Leydig cell }\end{array}$ & $\begin{array}{c}497 \pm 54 \\
862 \pm 84 \\
18402\end{array}$ & $\begin{array}{c}2130 \pm 232^{*} \\
804 \pm 37 \\
19918\end{array}$ \\
\hline
\end{tabular}

* Significantly different from the scrotal value $(P<0.001$, Student's paired $t$ test).

† Data from Damber et al. (1983). 

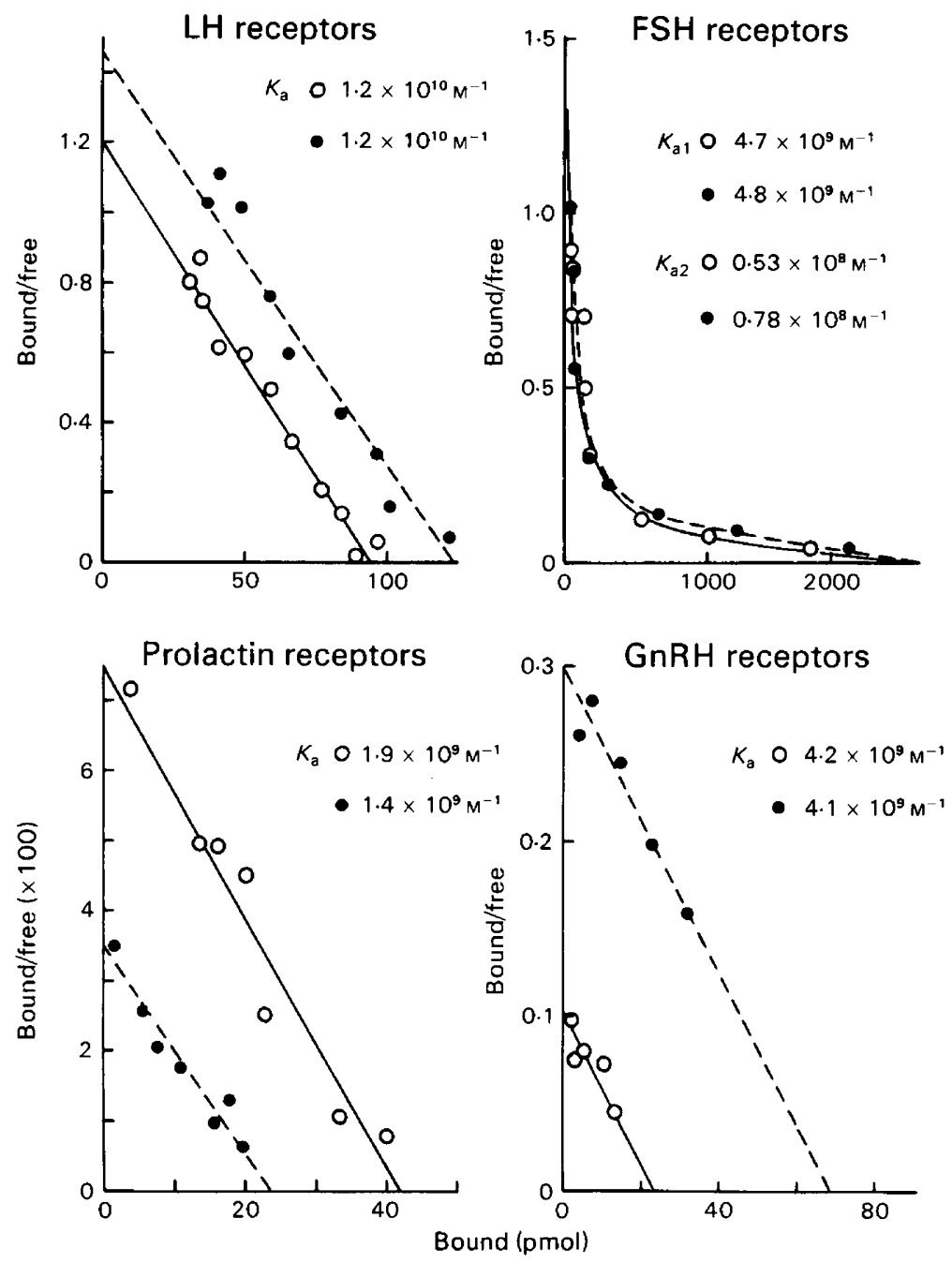

Text-fig. 1. Scatchard analysis of LH, FSH, prolactin and GnRH receptor measurements on pools of 3-5 scrotal $(O)$ and abdominal $(O)$ testes. One of 2-3 independent experiments with similar results is presented for each receptor. A high-affinity $\left(K_{\mathrm{a} 1}\right)$ and a low-affinity $\left(K_{\mathrm{a} 2}\right)$ component was found for the hFSH binding.

testes, respectively, $n=6$ for both) per testis were similar. The morphological appearance of these testes was as described earlier (Bergh \& Helander, 1978; Bergh \& Damber, 1978).

The results of the hormone receptor measurements are summarized in Text-fig. 1 and Table 1. The equilibrium association constants of $\mathrm{LH}, \mathrm{FSH}$, prolactin and GnRH receptors were similar to those presented for rat testicular tissue previously (Catt et al., 1976; Ketelslegers \& Catt, 1979; Huhtaniemi et al., 1983), and no apparent differences in these values were found for receptor binding in the scrotal and abdominal testes (Text-fig. 1): receptor numbers per abdominal testis were reduced to $0.27,0.31$ and 0.17 of those in the scrotal testis for FSH, LH and prolactin respectively. GnRH receptor values were not significantly changed. The results of the hormone measurements are summarized in Table 2. Intratesticular testosterone, but not progesterone concentration was decreased in abdominal testes. 
Table 2. Intratesticular concentrations (means \pm s.e.m.) of progesterone and testosterone in adult unilaterally cryptorchid rats

\begin{tabular}{lclcc}
\hline Steroid & $\begin{array}{c}\text { No. of } \\
\text { animals }\end{array}$ & Measurement & $\begin{array}{c}\text { Scrotal } \\
\text { testis }\end{array}$ & $\begin{array}{c}\text { Abdominal } \\
\text { testis }\end{array}$ \\
\hline Testosterone & 11 & ng/g & $30 \cdot 9 \pm 4 \cdot 4$ & $15 \cdot 4 \pm 3 \cdot 2^{* *}$ \\
Progesterone & 7 & ng/testis & $62 \cdot 2 \pm 8 \cdot 1$ & $6 \cdot 5 \pm 1 \cdot 3^{* *}$ \\
& & ng/g & $0.87 \pm 0 \cdot 10$ & $1 \cdot 01 \pm 0 \cdot 21$ \\
& & ng/testis & $1 \cdot 77 \pm 0 \cdot 21$ & $0.44 \pm 0 \cdot 10^{*}$ \\
\hline
\end{tabular}

Significantly different from scrotal value: ${ }^{*} P<0 \cdot 01,{ }^{* *} P<0 \cdot 001$ (Student's paired $t$ test).

\section{Discussion}

Despite the pronounced reduction in testicular weight, the number of Sertoli and Leydig cells was unaffected in abdominal testes. This is in agreement with the finding of a normal number of Sertoli cells in experimentally cryptorchid rams (Barenton et al., 1982) and "Sertoli cell only" rats (Bergh, 1981). Leydig cell number has previously been reported to be unaffected in this experimental model of cryptorchidism (Bergh \& Damber, 1978). The number of Sertoli cells (Wing \& Christensen, 1982) was similar but that of Leydig cells (Mori \& Christensen, 1980) was slightly less than in normal rat testis. The reason why Leydig and Sertoli cell numbers are equal in scrotal and abdominal testes is not known but could suggest that cellular numbers are mainly regulated by pituitary hormones affecting both testes equally. In this experimental model of cryptorchidism the earliest morphological changes probably occur in Sertoli cells. They are seen in the immature rat as soon as the contralateral descending testis leaves the abdominal cavity (Bergh, 1983a). At this stage of development Leydig cells appear unaffected (Bergh \& Damber, 1978). However, in adult animals Leydig cell function is impaired. The cell size (Bergh \& Damber, 1978), the basal secretion of testosterone (Damber, Bergh \& Janson, 1978), and the response to LH stimulation are subnormal (Damber \& Bergh, 1980). The present findings of low receptor and testosterone levels, normal progesterone and a changed testosterone:progesterone ratio in abdominal testes confirm our previous observations of impairment of Leydig cell steroidogenesis, probably at an enzymic step between progesterone and testosterone. The steroidogenic block could be related to the 4-fold increase in oestradiol levels in these testes (Damber, Bergh, Selstam \& Södergård, 1983). The reason for the reduced numbers of $\mathrm{LH}$ and prolactin receptors in abdominal testes is unknown but local factors are presumably involved. Some reports suggest that the Leydig cell malfunction in experimental cryptorchidism could be induced by the preceding Sertoli cell damage (de Kretser, 1982; Bergh, 1983b). An altered paracrine influence (Bergh, 1983b; Parvinen, Nikula \& Huhtaniemi, 1984) from the damaged Sertoli cells could be of significance, especially since FSH acting on Sertoli cells has a stimulatory influence on receptors for LH (Davies, 1981) and prolactin (Fishback, Animura \& Turkelson, 1982). The increased concentration of oestradiol may also be involved due to its demonstrated direct negative effects on Leydig cell LH (Saez, Haour, Loras, Saches \& Cathiard, 1978) and prolactin (Amit, Barkley \& Youdim, 1983) receptors. The number of GnRH receptors per Leydig cell was unchanged, in spite of the reduction in average cellular size (Bergh \& Damber, 1978). It has been suggested that a testicular 'GnRH-like' substance or some other Sertoli cell product serves as mediator of influences from the seminiferous tubules to the Leydig cells (see Sharpe, 1983). Effects of such tubular factors on Leydig cell GnRH receptors are not yet known. Nevertheless, unlike gonadotrophin and prolactin receptors, the maintenance of the GnRH receptor was not impaired by cryptorchidism. The number of oestradiol receptors was normal in abdominal testes (Damber et al., 1983), but the reason why these receptors were also unaffected remains unknown. It appears that receptors that are probably regulated by locally produced substances are unaffected, but those regulated by humoral factors are reduced in number. 
Most $\mathrm{LH}$, prolactin and GnRH receptors are localized on the Leydig cell plasma membrane. The cell volume of the average abdominal Leydig cell was reduced to about 0.5 of the value in the scrotal testis (Bergh \& Damber, 1978) and for geometric reasons the cell surface area is consequently less reduced (to 0.63 of the scrotal value if scrotal and abdominal Leydig cells are of similar shape). The $\mathrm{LH}$ and prolactin receptors were not changed to the same extent and both were reduced more than the cell surface area, although the $\mathrm{GnRH}$ receptors were unaffected. It is therefore unlikely that the change in receptor numbers was only a passive reflection of the decreased cell surface area.

The number of FSH receptors per Sertoli cell was decreased in the abdominal testes, and this is probably related to the disturbed Sertoli cell morphology (Bergh, 1983a), decreased basal ABP secretion (A. Bergh \& E. M. Ritzén, unpublished) and the subnormal FSH-stimulated lactate secretion from isolated tubules (A. Bergh, J. E. Damber, T. Nilsson \& H. Jacobsson, unpublished) in such testes.

In summary, the concentrations of several hormone receptors are decreased in the unilateral abdominal testis, suggesting that local factors within the testis are involved in their regulation.

This work was supported by grants from the Medical Research Council in Sweden (Project 5935), Maud and Birger Gustavsson foundation, and the Medical Research Council of the Academy of Finland.

\section{References}

Amit, T., Barkley, R.J. \& Youdim, M.B.H. (1983) Effect of prolactin, testosterone and estrogen on prolactin binding in the rat testis, prostate, seminal vesicle and liver. Molec. cell. Endocr. 30, 179-187.

Barenton, B., Blanc, M.R., Caraty, A., Hochereau-de Reviers, M.T., Perreau, C. \& Saumande, J. (1982) Effect of cryptorchidism in the ram: changes in the concentration of testosterone and estradiol and receptors for $\mathrm{LH}$ and $\mathrm{FSH}$ in the testis and its histology. Molec. cell. Endocr. 28, 13-25.

Bergh, A. (1981) Morphological signs of a direct effect of experimental cryptorchidism on the Sertoli cells in rats irradiated as fetuses. Biol. Reprod. 24, 145152.

Bergh, A. (1983a) Early morphological changes in the abdominal testes in immature unilaterally cryptorchid rats. Int. J. Androl. 6, 73-90.

Bergh, A. (1983b) Paracrine regulation of Leydig cells by the seminiferous tubules. Int. J. Androl. 6, 57-65.

Bergh, A. \& Damber, J.-E. (1978) Morphometric and functional investigation on the Leydig cells in experimental unilateral cryptorchidism in the rat. Int. J. Androl. 1, 549-562.

Bergh, A. \& Helander, H.F. (1978) Testicular development in the unilaterally cryptorchid rat. Int. $J$. Androl. 1, 440-458.

Catt, K.J. Ketelslegers, J.-M. \& Dufau, M.L. (1976) Receptors for gonadotropic hormones. In Methods in Receptor Research, Vol. 1, pp. 175-250. Ed. M. Blecher. Marcel Dekker, New York.

Clayton, R.N., Shakespear, R.A. \& Marshall, J.C. (1979) Radiodinated non-degradable gonadotrophin releasing hormone analogs; new probes for investigation of pituitary gonadotrophin releasing hormone receptors. Endocrinology 105, 1369-1381.

Damber, J.-E. \& Bergh, A. (1980) Decreased testicular response to acute LH-stimulation and increased intratesticular concentration of oestradiol-17-beta in the abdominal testes in cryptorchid rats. Acta endocr., Copenh. 95, 416-421.

Damber, J.-E., Bergh, A. \& Janson, P. O. (1978) Testicular blood flow and testosterone concentration in the spermatic venous blood in rats with experimental cryptorchidism. Acta endocr., Copenh. 88, 611-618.

Damber, J.-E., Bergh, A., Selstam, G. \& Südergård, R. (1983) Oestradiol receptor binding capacity and aromatase activity in the testes of the experimental unilateral cryptorchid rat. Archs Androl. 11, 259263.

Davies, A.G. (1981) Role of FSH in the control of testicular function. Archs Androl. 17, 97-108.

de Kretser, D.M. (1982) Sertoli cell-Leydig cell interaction in regulation of testicular function. Int. J. Androl., Suppl. 5, 11-17.

Fishback, J.B., Animura, A. \& Turkelson, C.M. (1982) Effects of an LHRH against and gonadotropines on testicular prolactin receptors. Peptides 3, 845-850.

Hagenäs, L., Ritzén, E.M., Svensson, J. \& Hansson, V. (1978) Temperature dependence of Sertoli cell function. Int. J. Androl., Suppl. 2, 449-458.

Hammond, G.L., Viinikka, L. \& Vihko, R. (1977) Automation of radioimmunoassays for some sex steroids with use of both iodinated and tritiated ligands. Clin. Chem. 23, 1250-1257.

Hochberg, Z., Amit, T., Youdim, M.B.H. \& Jehuda, A.B.-M. (1983) Prolactin binding by testes of unilaterally cryptorchid rat: effect of hCG, testosterone, prolactin and orchiopexy. Acta endocr., Copenh. 102, 144-149.

Huhtaniemi, I.T., Warren, D.W. \& Catt, K.J. (1983) Development of heterologous down-regulation of lactogen receptors in the rat testis. Molec. cell. Endocr. 29, 287-294. 
Huhtaniemi, I.T., Stewart, J.K., Chamnabasavaiah, K., Fraser, H.M. \& Clayton, R.N. (1984) Effect of treatment with GnRH antagonist, GnRH antiserum and bromocriptine on pituitary-testicular function of adult rats. Molec. cell. Endocr. 34, 125-135.

Jänne, O., Apter, D. \& Vihko, R. (1974) Assay of testosterone, progesterone and 17-beta-hydroxyprogesterone in human plasma by radioimmunoassay after separation on hydroxyalkoxypropyl cephadex. J. Steroid Biochem. 5, 155-162.

Kerr, J.B., Rich, K.A. \& de Kretser, D.M. (1979a) Effects of experimental cryptorchidism on the ultrastructure and function of the Sertoli cell and peritubular tissue of the rat testis. Biol. Reprod. 21, 823-838.

Kerr, J.B., Rich, K.A. \& de Kretser, D.M. (1979b) Alterations of the fine structure and androgen secretion of the interstitial cells in the experimentally cryptorchid rat testis. Biol. Reprod. 20, 409-422.

Ketelslegers, J.-M. \& Catt, K.J. (1978) Follitropin receptors in the rat testis, characterization with enzymatically ${ }^{125}$ I-labelled human follitropin. Biochim. Biophys. Acta 541, 360-371.

Mori, H. \& Christensen, A.K. (1980) Morphometric analysis of Leydig cells in the normal rat testis. $J$. Cell Biol. 84, 340-354.
Parvinen, M., Nikula, H. \& Huhtaniemi, I. (1984) Influence of rat seminiferous tubules on Leydig cell testosterone production in vitro. Molec. cell. Endocr. 37, 331-336.

Risbridger, G.P., Kerr, J.B., Peake, R.A. \& de Kretser, D.M. (1981) An assessment of Leydig cell function after bilateral or unilateral efferent duct ligation: further evidence for local control of Leydig cell function. Endocrinology 109, 1234-1241.

Saez, J.M., Haour, F., Loras, B., Saches, P. \& Cathiard, A.M. (1978) Estrogen induced Leydig cell refractions to gonadotrophin stimulation. Acta endocr., Copenh. 89, 379-392.

Sharpe, R.M. (1983) Local control of testicular function. Q. Il exp. Physiol. 68, 265-287.

VanDemark, N.L. \& Free, M.J. (1970) Temperature effects. In The Testis, Vol. III, pp. 233-312. Eds A. D. Johnson, W. R. Gomez \& N. L. VanDemark. Academic Press, New York.

Weibel, E.R. (1979) Stereological Methods, vol. 1, p. 44. Academic Press, London.

Wing, T.Y. \& Christensen, A.K. (1982) Morphometric studies on rat seminiferous tubules. Am.J. Anat. 165, 13-25.

Received 11 October 1984 